\title{
Birds and bats captured in a managed forest in Southwestern Brazilian Amazonia: Results and recommendations from a short-term study
}

\author{
Diego Pedroza $^{1}{ }^{*}$, Rair de Sousa Verde ${ }^{1}$ and Edson Guilherme ${ }^{2}$
}

${ }^{1}$ Graduate Program in Ecology and Natural Resource Management. Universidade Federal do Acre (UFAC). BR-364, km 04. Distrito Industrial. Sala 03 do PPG-EMRN. Bloco da Pós-Graduação. Rio Branco-AC, Brazil (CEP 69920-900). *Email: diego.guima1@hotmail.com.

${ }^{2}$ Center for Biological and Natural Sciences. Universidade Federal do Acre (UFAC). BR-364, km 04. Distrito Industrial. Sala 03 do PPG-EMRN. Bloco da Pós-Graduação. Rio Branco-AC, Brazil (CEP 69920-900).

\begin{abstract}
Understanding the activity pattern and the height of capture of birds and bats can help to optimize the sampling of both groups. Our aimed was to determine the rates of capture at different times of day/night, and the overlap in the height of capture; classify the trophic guilds, and check variation in the capture rates of the birds and bats. We conducted the study in the Antimary State Forest, in March, 2017. We set mist-nets at the same location during five consecutive days, and were open between 06:00 $\mathrm{h}$ and 00:00 $\mathrm{h}$. The birds presented a bimodal activity pattern, as well as bats. Bats were captured at higher levels than birds. Most of the birds captured were insectivores, where as most of the bats were frugivores. Neither group presented a clear pattern of variation in capture rates. Therefore, the first hours of the morning are fundamental for the capture of birds. For bats, we would recommend the captures only after 17:00 h. Mist-nets should be set at ground level for birds, whereas for bats, they should be set above a height of 0.5 $\mathrm{m}$. Thus, the captures should be optimized.
\end{abstract}

Keywords: Bird activity; Bat activity; Activity pattern; Capture efficiency; Short-term.

\section{Introduction}

Birds and bats are two highly diverse vertebrate groups found in the
Received

February 22, 2019

Accepted

March 23, 2019

Released

April 30, 2019

Full Text Article

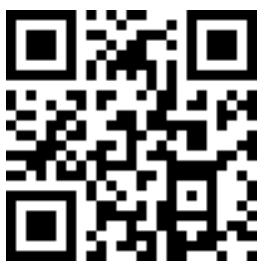

\footnotetext{
ORCID

D 0000-0003-3119-199X Diego Pedroza

(ㄷ) 0000-0003-2275-4324

Rair de Sousa Verde

(1) 0000-0001-8322-1770

Edson Guilherme
}

principal biomes of the Neotropical region (Stotz et al., 1996; Marques et al., 2013; Voigt and Kingston, 2016). In both cases, specimens can be captured using 
mist-nets (Meyer et al., 2011, Marques et al., 2013). In the case of the birds, visual and auditory sampling can also be used to complete the inventory (Whitman, 2004; Blake and Loiselle, 2009; Marques et al., 2013). In bats, mist-netting is the principal sampling method (Meyer et al., 2011), although high-frequency echolocation recorders have been used increasingly in recent years to conduct acoustic surveys (Stahlschmidt and Brühl 2012). One disadvantage of the use of mist-nets is that, after a certain time in the same location, both birds and bats appear to be able to learn the location of the nets and avoid them (Esbérard, 2006; Marques et al., 2013). Even so, mist-nets are considered to be relatively effective for the inventory of both groups of vertebrates (Bernard, 2001; Johnson et al., 2011), as well as the monitoring of activity patterns (Trnka et al., 2006; Verde et al., 2018).

In general, the activity patterns of the two groups are distinct, with birds being active predominantly in the morning and afternoon periods, and bats, at night. Tropical birds tend to be active primarily during the early hours of the morning and late afternoon, in a typical bimodal pattern (Gilardi and Munn, 1998; Salina-Melgoza and Renton, 2005; Brandt and Cresswell, 2009; Dias et al., 2016). In other regions, however, the seasonal changes in day length, with shorter days in the winter and longer ones during the summer, influence bird activity patterns (Rollfinke and Yahner, 1990; Reyes-Arriagada et al., 2015; Silva et al., 2015). The climate, in particular temperature, but also rainfall, may also affect these patterns (Boyes and Perrin, 2010; Reyes-Arriagada et al,, 2015). Similar variation is observed in bats (Speakman et al., 2000; Thies et al., 2006), which are predominantly nocturnal (Presley et al., 2009, Verde et al., 2018). In the Amazon region, for example, bats are active primarily during the first hours of the night, with activity then declining progressively until shortly before dawn, when foraging increases once again, in a bimodal pattern (Bernard and Fenton, 2002; Presley et al., 2009; Verde et al., 2018).

Birds and bats forage in different forest strata (Bonter et al., 2008; Pereira et al., 2010). This is determined primarily by the availability of feeding resources and the foraging adaptations of the different species (Rosenberg, 1990; Pereira et al., 2010). Birds forage at different levels in the forest to avoid interspecific competition, and the preference for a given stratum may vary according to the trophic guild (Collins, 2015), with a similar pattern being observed in bats (Bernard, 2001; Pereira et al., 2010). Bats also present a range of behavioral, morphological, and physiological adaptations for foraging, which are observed in their foraging behavior and mold their activity patterns (Schnitzler and Kalko, 2001).

In the understory of the Amazon forest, most species of bird and bat belong to distinct guilds. Most of the bats captured in the understory are frugivores (Bernard, 2001; Pereira et al., 2010), whereas most of the birds found in this stratum are insectivores (Johnson et al., 2011). There is also little overlap in the diets of frugivorous birds and bats, given that few of the same types of fruit are exploited by the two taxa (Gorchov et al., 1995). In the case of insectivory, few prey are shared (Rydell and Speakman, 1995; Speakman et al., 2000), due in particular to the asynchronous timing of the foraging activity of bats and birds (Rydell and Speakman, 1995).

Many bird and bat species are captured only rarely or never at all in mist-nets due to a number of factors, in particular the fact that they extend to a height of $3 \mathrm{~m}$, which is below the levels at which many species typically fly (Rosenberg, 1990; Bonter et al., 2008). Even when they do fly lower down, some individuals (both birds and bats) may be able to learn the location of the mist-nets (Marques et al., 2013), and some bats appear to be able detect the nets by echolocation (Duchamp et al., 2006; 
Meyer et al., 2011) Many studies have shown that mist-nets that remain in a given position for a long period of time tend to become progressively ineffective for the capture of specimens (Faaborg et al., 2004; Marques et al., 2013). This indicates that individuals are memorizing the location of the nets, which allows them to avoid being captured. For this reason, most researchers will alter the position of their nets constantly, to optimize captures (Whitman, 2004; Marques et al., 2013). In this context, it is important to be able to evaluate the best possible approaches available for the sampling of the target groups, according to the objectives of the study (Marques et al., 2013), in particular during studies of limited duration. Data on daily activity patterns and the height of capture may also provide important insights into the optimal use of mist-nets for the sampling of bird and bat assemblages in the Amazon Region.

Given these objectives, the present study aimed to determine (1) the rates of capture of birds and bats during different times of day/night, (2) the degree of overlap in the height of capture of the birds and bats in the mist-nets, (3) the trophic guilds represented by the birds and bats captured, and (4) the variation in the capture rates of birds and bats among the five consecutive days of sampling. Based on the results of the study, we provide a number of recommendations for the optimization of the capture of birds and bats by mistnetting in southwestern Amazonia.

\section{Materials and methods}

\section{Study site}

We conducted the study in the 77,000-hectare Antimary State Forest (FEA), an area of forestry management in the State of Acre, Brazil $\left(9^{\circ} 31^{\prime} 00^{\prime \prime} \mathrm{S}\right.$, $68^{\circ} 23^{\prime} 00^{\prime \prime} \mathrm{W}$ ), in Southwestern Amazonia. The FEA is covered with open rainforest, with bamboo and palms, and dense lowland rainforest, with an emergent canopy (Acre, 2000). The mean annual temperature in the region is between $22^{\circ} \mathrm{C}$ and $33{ }^{\circ} \mathrm{C}$, and annual precipitation is 1,600-2,750 $\mathrm{mm}$ (Aquino et al., 2011). The region's climate is hot and humid, with a rainy season between November and April, and a dry season from May to October (Schaefer, 2013).

\section{Capture method}

We captured birds and bats at the site simultaneously and continuously between March 19 and 23, 2017, which includes the rainy season in the region. We used 12 mist-nets of $12 \mathrm{~m} \times 2.5 \mathrm{~m}$, set at ground level up to a height of $2.5 \mathrm{~m}$, forming a continuous transect line. We maintained the mist-nets in the same position throughout the five days of the study period. The nets were opened at 06:00 $\mathrm{h}$ and closed at 00:00 $\mathrm{h}$, providing a sampling effort of 216 net-hours per day. The nets were checked once per hour.

\section{guild \\ Rate, capture variation and \\ To determine the activity pattern} of the bats and birds, we calculated a capture rate $\left(r_{i}\right)$ per hour of the day/night (number of individuals captured $\left.\mathrm{m}^{-2} \mathrm{~h}^{-1}\right)$ as $r_{i}=n_{i} /($ a.d $)$, where $n_{i}=$ the number of individuals captured in hour $i, a=$ the area of mist-net in $\mathrm{m}^{2}$, and $d=$ the number of hours the nets were open (Trnka et al., 2006). We used a surveyor's tape to determine the height of capture of each specimen. The mean height of capture was calculated for each taxonomic group (birds and bats). We also registered the number of captures for each group per day, to determine the possible variation in the number of specimens captured over the duration of the study. We identified all captured specimens to species, which allowed us to determine the trophic guild of each taxon. We classified the bird guilds according to Wilman et al. (2014), and those of the bats based on Kalko (1998) and Wilman et al. (2014). 


\section{Data analysis}

We used a $t$ test to verify whether birds and bats were captured at significantly different heights in the mistnets. We ran this analysis in the vegan package of the $\mathrm{R}$ platform, version 3.0.3 (R Core Team, 2017). Confirming that the data satisfied the assumptions of normality, using the Shapiro-Wilk Test, and based on Levene's Test, the homoscedasticity of variance.

\section{Results}

We captured 56 indivíduos (29 birds and 27 bats) during 1,080 net- hours of sampling. The birds captured belonged to nine families, 15 genera, and 17 species (Table 1 ), while the bats represented two families, eight genera, and 12 species (Table 2). The hourly capture rates (Figure 1) indicated a bimodal diurnal pattern for the birds, with two principal peaks, one at 07:00 h, and the other between 14:00 $\mathrm{h}$ and 16:00 $\mathrm{h}$. The bats also presented two major peaks in activity, at night, one at 19:00 h, and the other at 23:00 h. The only overlap between the two groups was observed at 17:00 h (Figure 1).

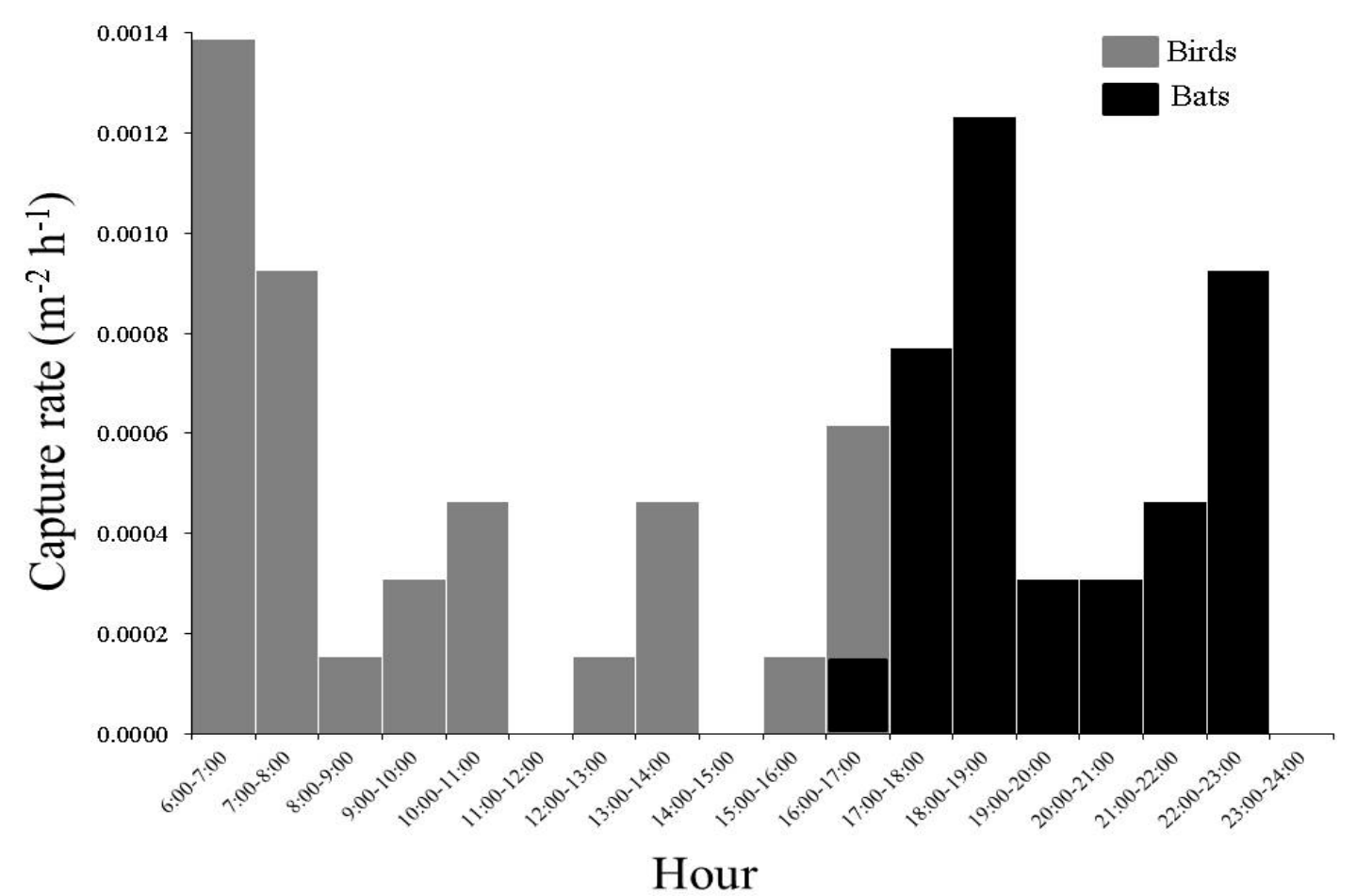

Figure 1. Capture rates per hour of the day/night of the birds and bats trapped in mists nets on five consecutive days in an area of forestry management in Southwestern Amazonia.

On average, the birds were captured at a mean height of $0.67 \mathrm{~m}$ $(\mathrm{SD}=0.53 \mathrm{~m})$ (Figure 2), whereas bats were captured at a height of $1.15 \mathrm{~m}$ $(\mathrm{SD}=0.60 \mathrm{~m})$, with a significant difference being found between the two means $\quad(t=-3.13, \quad P=0.003)$. Insectivorous birds were collected more frequently than insectivorous bats (Figure 3), whereas frugivorous bats predominated. Two omnivorous birds, Geotrygon montana (Linnaeus, 1758) and Cyanoloxia rothschildii (Bartlett, 1890), and one bat, Phyostomus elongatus (É. Geoffroy, 1810), were also collected (Figure 3). 


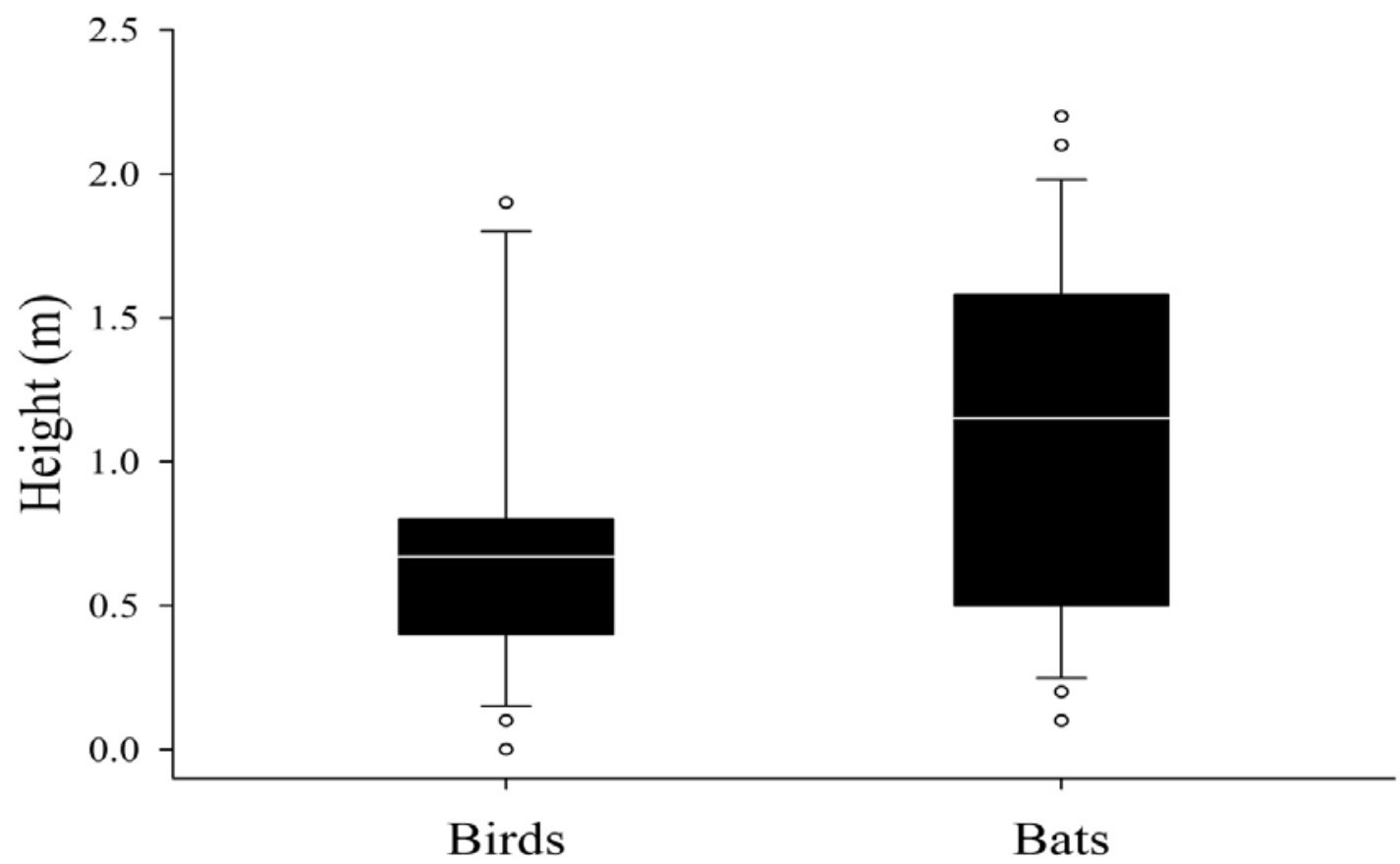

Figure 2. Box plots of the height at which the birds and bats were captured in the present study in an area of managed forestry in southwestern Brazilian Amazonia. The boxes represent 50\% of the data collected for each group, between the 25 th and 75 th percentiles, with the mean indicated by the horizontal midline, and the whiskers, the 10th and 90th percentiles (standard deviation). Outliers are shown as circles. The nets extended from ground level to a height of $2.5 \mathrm{~m}$.

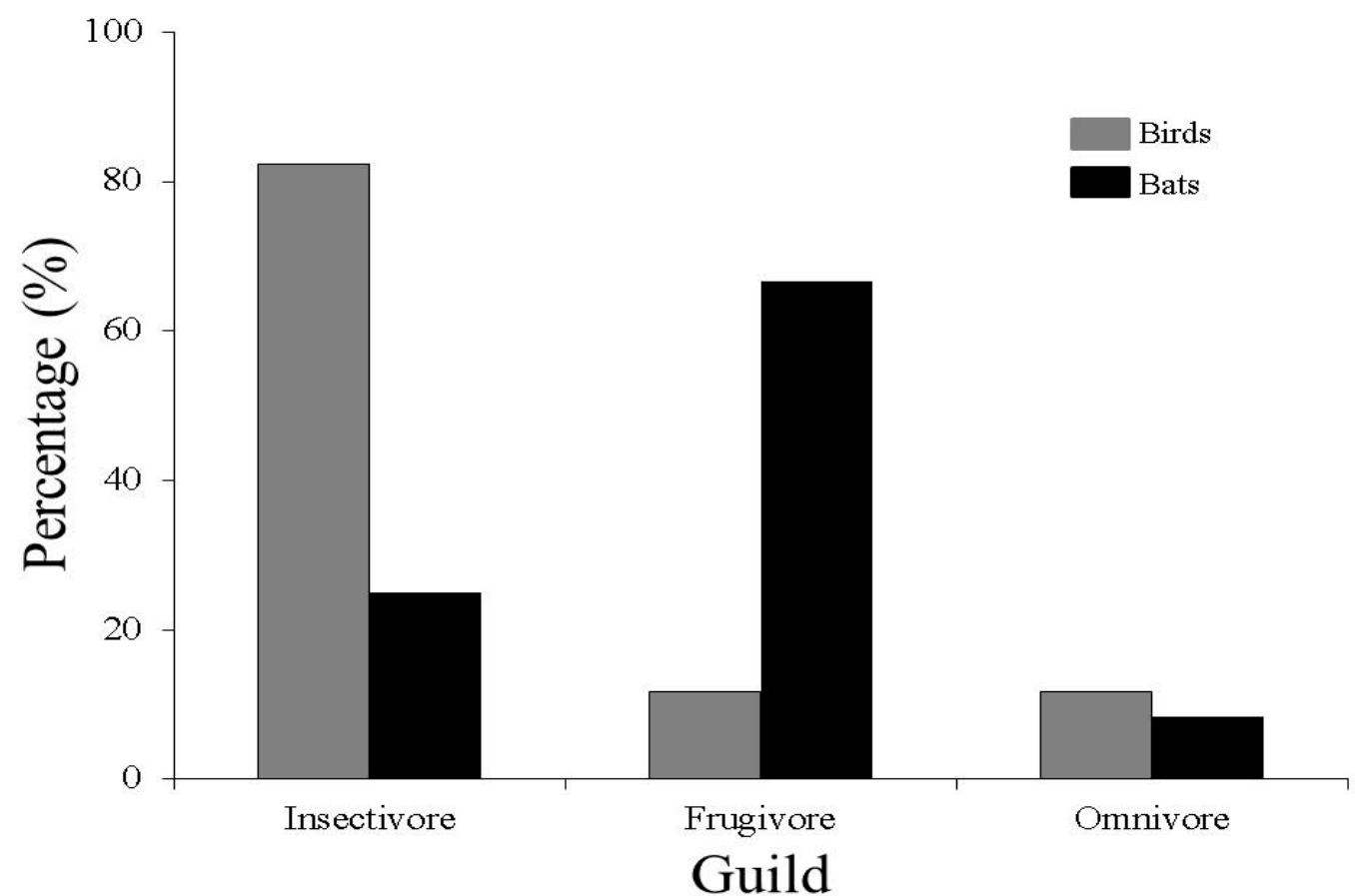

Figure 3. Contribution (percentage) of the different trophic guilds of birds and bats captured in the present study in an area of managed forest in Southwestern Brazilian Amazonia. 
No systematic variation was observed among days in the capture of birds or bats (Figure 4). In both groups, the number of specimens collected on the first day was relatively low, then peaking on the second (bats) or third (birds) days. In the bats, the number of captures remained virtually constant after the second day, whereas in the birds, there was an abrupt decline on the third day, followed by a slight increase.

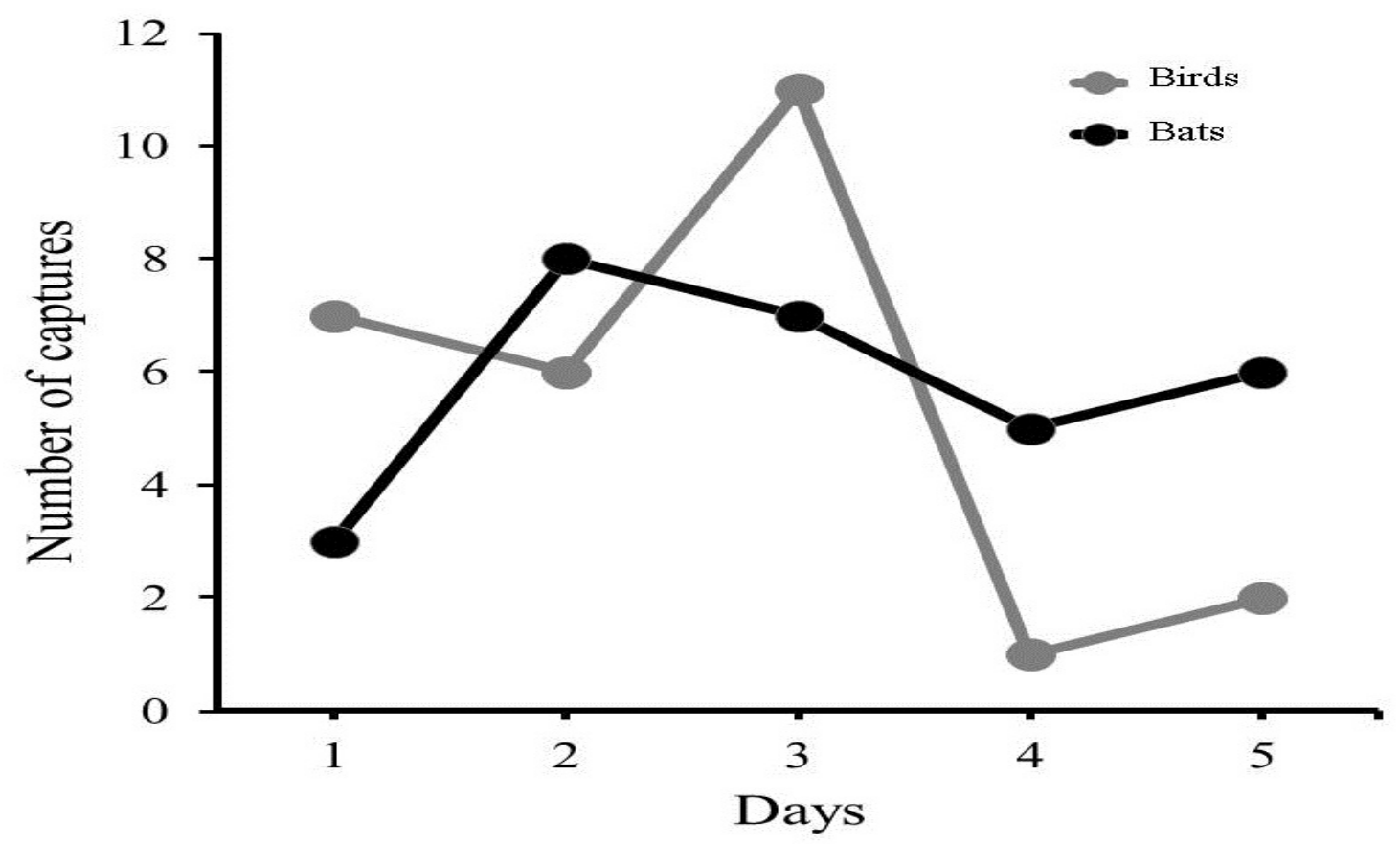

Figure 4. Number of birds and bats captured on each of the five consecutive days of mist-netting in a managed forest in southwestern Amazonia.

Table 1. Bird species captured in an area of forestry management in the Antimary State Forest in Acre, Brazil.

\begin{tabular}{|c|c|c|}
\hline $\begin{array}{l}\text { Order } \\
\text { Family } \\
\text { Subfamily } \\
\text { Species }\end{array}$ & TG & $\mathbf{N}$ \\
\hline
\end{tabular}

COLUMBIFORMES Latham, 1790

COLUMBIDAE Leach, 1820

Geotrygon montana (Linnaeus, 1758)

OM 1

PASSERIFORMES Linnaeus, 1758

TYRANNI Wetmore and Miller, 1926

THAMNOPHILIDA Patterson, 1987

THAMNOPHILIDAE Swainson, 1824 
Table 1. Continued.

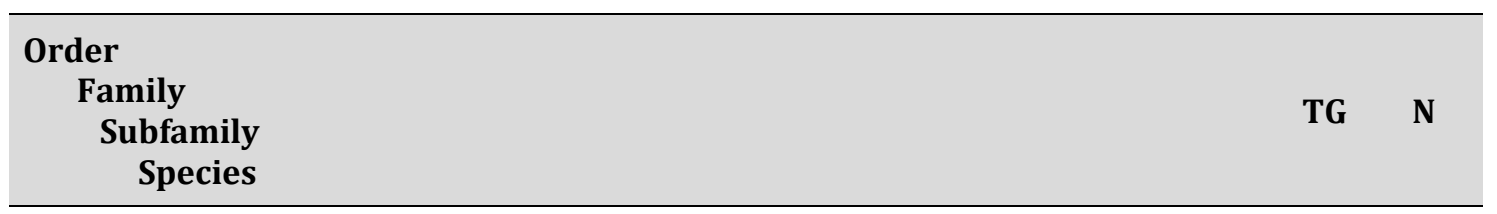

THAMNOPHILINAE Swainson, 1824

Epinecrophylla haematonota (Sclater, 1857)

Thamnomanes ardesiacus (Sclater and Salvin, 1867)

Thamnomanes schistogynus Hellmayr, 1911

Sciaphylax hemimelaena (Sclater, 1857)

Cercomacroides nigrescens (Cabanis and Heine, 1859)

Willisornis poecilinotus (Cabanis, 1847)

Oneillornis salvini (Berlepsch, 1901)

$\begin{array}{ll}\text { IN } & 4 \\ \text { IN } & 1 \\ \text { IN } & 2 \\ \text { IN } & 1 \\ \text { IN } & 1 \\ \text { IN } & 2 \\ \text { IN } & 1\end{array}$

DENDROCOLAPTIDAE Gray, 1840

SITTASOMINAE Ridgway, 1911

Dendrocincla fuliginosa (Vieillot, 1818)

\section{DENDROCOLAPTINAE Gray, 1840}

Glyphorynchus spirurus (Vieillot, 1819)

Xiphorhynchus ocellatus (Spix, 1824)

Xiphorhynchus elegans (Pelzeln, 1868)

XENOPIDAE Bonaparte, 1854

Xenops tenuirostris Pelzeln, 1859

TYRANNIDA Wetmore and Miller, 1926

PIPRIDAE Rafinesque, 1815

PIPRINAE Rafinesque, 1815

Lepidothrix coronata (Spix, 1825)

ONYCHORHYNCHIDAE Tello, Moyle, Marchese and Cracraft, 2009

Onychorhynchus coronatus (Statius Muller, 1776)

TROGLODYTIDAE Swainson, 1831

Microcerculus marginatus (Sclater, 1855)

CARDINALIDAE Ridgway, 1901

Cyanoloxia rothschildii (Bartlett, 1890)

OM 1

$\mathrm{TG}=$ Trophic Guild; $\mathrm{N}=$ Number of individuals captured; $\mathrm{FR}=$ Frugivore; $\mathrm{OM}=$ Omnivore, IN = Insectivore. 
Table2. Bat species captured in an area of forestry management in the Antimary State Forest in Acre, Brazil.

\begin{tabular}{ccc}
\hline $\begin{array}{l}\text { Family } \\
\text { Subfamily } \\
\text { Species }\end{array}$ & TG & $\mathbf{N}$ \\
\hline
\end{tabular}

PHYLLOSTOMIDAE Gray, 1825

CAROLLINAE Miller, 1924

Carollia brevicauda (Schinz, 1821)

FR 2

Carollia perspicillata (Linnaeus, 1758)

FR 5

RHINOPHYLLINAE Baker et al., 2016

Rhinophylla fischerae Carter, 1966

FR 1

Rhinophylla pumilio Peters, 1865

FR 4

PHYLLOSTOMINAE Gray, 1825

Lophostoma silvicola d'Orbigny, 1836

IN 2

Phyllostomus elongatus (É. Geoffroy, 1810)

OM 2

Tonatia saurophila Koopman and Williams, 1951

IN 3

STENODERMATINAE Gervais, 1856

Artibeus lituratus (Olfers, 1818)

FR 3

Artibeus obscurus (Schinz, 1821)

FR 1

Artibeus planirostris (Spix, 1823)

FR 1

Dermanura cinereus (Gervais, 1856)

FR 2

THYROPTERIDAE Spix, 1823

Tyroptera tricolor Spix, 1823

IN 1

TG = Trophic Guild, $\mathrm{N}=$ Number of individuals captured. FR = Frugivore, $\mathrm{OM}=$ Omnivore, $\mathrm{IN}=$ Insectivore.

\section{Discussion}

During the five days of the study period, it was possible to verify the daily activity pattern of the birds, which presented a well-defined bimodal distribution (Figure 1). Activity peaked during the first two hours of the morning, followed by a lesser peak prior to sunset. A similar bimodal activity pattern has been observed in birds in many other tropical regions (Gilardiand Munn, 1998; Salina-Melgoza and Renton,
2005; Brandt and Cresswell, 2009; Dias et al., 2016), as well as in the Northern hemisphere, for example, in Slovakia (Trnka et al., 2006).

In the bats, the nocturnal activity recorded up to midnight also presented what appeared to be a bimodal pattern, with one peak at the beginning of the night, and the other, near midnight (Figure 1). Other studies in the Amazon region have shown that bat activity tends to peak at the beginning and end of the night (Bernard and Fenton, 2002; Verde 
et al., 2018), when the whole nocturnal period is monitored. Capture rates may also be influenced by other factors, such as the type of habitat (Lövei et al., 2001), climatic conditions (Thies et al., 2006), and even the avoidance of moonlight (Mello et al., 2013), in the specific case of non-insectivorous bats, for these that foraging just after the sunset is adaptive (Appel et al., 2017). Given this, we would recommend comparing the activity pattern of bats in preserved and managed forests during the whole nocturnal period, to verify possible differences among habitats.

Capture heights were significantly different between birds and bats (Figure 2), with birds typically being captured at heights of around $0.5 \mathrm{~m}$ above the ground, and bats a meter higher. This may be related, in part, to the differences in feeding guilds between the two groups, given that the majority of the birds we captured were insectivores (Figure 3), a pattern expected in Amazonian forests (Terborgh et al., 1990; Johnson et al., 2011). Some resources, such as fruit, can be scarce in the understory (Gentry and Emmons, 1987), supporting only a reduced diversity of frugivores (Johnson et al., 2011), with frugivorous birds being captured more rarely in the understory. The predominance of frugivorous bats was also expected for an Amazonian forest in the understory (Bernard, 2001; Rex et al., 2011). When fruit is available, it is normally found in the upper crowns of the understory shrubs and trees (Gentry and Emmons, 1987), which would account for the almost complete absence of bats captured at heights of below $0.5 \mathrm{~m}$.

The number of individuals captured varied considerably among days, for both birds and bats. The number of individuals of either group captured during a given session may vary according to four principal factors: (1) High levels of rainfall, which typically reduce foraging activity in both birds (O'Connor and Hicks, 1980) and bats
(Erickson and West, 2002). (2) Temperature. In Southwestern Amazonia, between May and June, cold fronts derived from polar air masses reduce ambient temperatures to approximately $10{ }^{\circ} \mathrm{C}$ (Acre, 2000; Duarte, 2007). These events are known locally as the friagem (cold snaps). While these events last only a few days, they may result in a considerable reduction in the activity of birds and mammals within the forest. (3) Learning and detection of mist-net. Birds and bats can learn the location of nets and bats can detect them by echolocation (Marques et al., 2013; Duchamp et al., 2006; Meyer et al., 2011) (4) Mixed bands and army ants (birds only). Heterospecific bands of birds that associate with army ants involve large numbers of individuals moving through the forest in a coordinated manner (Oniki and Willis, 1972; Willis and Oniki, 1978), which may result in a considerable increase in the number of individuals captured on a given day. In the absence of this phenomenon, capture rates return to normal. (5) Avoidance of moonlight (non-insectivorous bats only). During nights with brighter moonlight, the number of bats in activity decreases considerably due to the increase in the risk of predation (Appel et al. 2017).

\section{Conclusions}

Based on this evidence, we suggest the following recommendations.

Timing of captures: The optimal time of day for the capture of birds within the forest of southwestern Amazonia was the first three hours of daylight. In studies of birds, we recommend that the nets are closed prior to $17: 00 \mathrm{~h}$ to avoid capturing bats, and in studies of bats, the nets should be opened only after $17: 00 \mathrm{~h}$, to avoid capturing birds.

Net height: To capture understory birds, we recommend setting the nets at ground level. However, setting mist-nets at heights of less than $0.5 \mathrm{~m}$ is ineffective for the capture of bats. In 
order to optimize the capture potential of the nets for bats, the nets should be set at heights of above $0.5 \mathrm{~m}$.

Mist-net: Stay for many days in the same site or to change every three or five days: The benefits of shifting the site of the mist-nets will depend on the objectives of the study, although other factors that may interfere in capture rates, such as rainfall (for both birds and bats) and the moon phase (for bats), should also be taken into account. During rainy periods, the nets should be managed for longer periods in the same site, to optimize the capture of birds and bats, whereas during drier periods llow precipitation), five consecutive days is the maximum period recommended. This is because, during periods with low levels of precipitation, birds $\left(\mathrm{O}^{\prime}\right.$ Connor and Hicks, 1980) and bats (Erickson and West, 2002) are more active overall, which increases the probability of capture. The only exception in the study region would be during the cold snaps (sensu Parmenter, 1976), when both birds and bats may become less active. We would thus not recommend setting the nets during these events. In the specific case of the bats, on nights with more moonlight, we would recommend setting the nets only until moonrise, or not at all. On moonlit nights, bat capture rates may decrease drastically (Mello et al., 2013). By following these simple recommendations, researchers can obtain optimal mist-netting results for birds and bats in Amazonian forest environments, considering the pay-off between costs (sampling effort) and benefits (capture rates).

\section{Acknowledgments}

We are grateful to the Federal University of Acre (UFAC) and the administration of the Antimary State Forest (FEA) for logistic support. The FEA also provided lodging and provisions. We are also grateful to $\mathrm{CNPq}$ and CAPES for providing the authors with stipends, and the UFAC Masters
Program in Ecology and Natural Resource Management for support. We would also like to thank Dr. Lisandro Juno, Dr. Moises Barbosa, Dr. Fabiano Corrêa, Dr. Elder Morato, and Dr. Armando Muniz Calouro for their valuable suggestions and help in the field. We would also like to thank Dr. Stephen F. Ferrari for translating and correcting the text, and for providing valuable suggestions on its content.

\section{Conflict of interest}

The authors declare that they have no conflict of interest.

\section{References}

Acre. Governo do Estado do Acre. Programa Estadual de Zoneamento EcológicoEconômico do Estado do Acre - ZEE Documento Final. Rio Branco: SECTAMA, 2000.

Appel, G.; López-Baucells, A.; Magnusson, W. E.; Bobrowiec, P. E. D. Aerial insectivorous bat activity in relation to moonlight intensity. Mammalian Biology, v. 85, p. 37-46, 2017. https://doi.org/10.1016/j.mambio.2016.11.0 05

Aquino, M. L. R. S.; Lima, E. R. V.; Silva, Z. A. G. P. G. Manejo madeireiro na floresta estadual do Antimary, Estado do Acre, Brasil. Revista NERA, v. 14, p. 104-135, 2011.

Bernard, E. Vertical stratification of bat communities in primary forest of Central Amazon, Brazil. Journal of Tropical Ecology, v. 17, no. 1, p.115-126, 2001. https://doi.org/10.1017/S02664674010010 79

Bernard, E.; Fenton, M. B. Species diversity of bats (Mammalia: Chiroptera) in forest fragments, primary forests, and savannas in central Amazonia, Brazil. Canadian Journal of Zoology, v. 80, no. 6, p. 1124-1140, 2002. https://doi.org/10.1139/z02-094

Blake, J. G; Loiselle, B. A. Species composition of Neotropical understory bird communities: local versus regional perspectives based on capture data. Biotropica, v. 41 , no. 1, p. 8594, 2009. https://doi.org/10.1111/j.17447429.2008.00445.x 
Bonter, D. N.; Brooks, E. W.; Donovan, T. M. What are we missing with only ground-level mist nets? Using elevated nets at a migration stopover site. Journal Field Ornithology, v. 79, no. $3, \quad$ p. 314-320, 2008. https://doi.org/10.1111/j.1557-9263.2008. 00179.x

Boyes, R. S.; Perrin, M. R. Patterns of daily activity of Meyer's parrot (Poicephalus meyeri) in the Okavango Delta, Botswana. Emu - Austral Ornithology, v. 110, p. 54-65, 2010. https://doi.org/10.1071/MU09067

Brandt, M. J.; Cresswell, W. Diurnal foraging routines in a tropical bird, the rock finch Lagonosticta sanguinodorsalis: how important is predation risk? Journal Avian Biology, v. 40, no. 1, p.90-94, 2009. https://doi.org/10.1111/j.1600-048X.2008. 04389.x

Collins, C. T. Food habits and resource partitioning in a guild of Neotropical swifts. The Wilson Journal of Ornithology, v. 127, no. 2, p. 239-248, 2015. https://doi.org/ 10.1676/wils-127-02-239-248.1

Dias, L. C. S.; São Bernardo, C. S.; SrbekAraujo, A.C. Daily and seasonal activity patterns of the Solitary Tinamou (Tinamus solitarius) in the Atlantic Forest of southeastern Brazil. The Wilson Journal of Ornithology, v. 128, no. 4, p. 885-894, 2016. https://doi.org/10.1676/15-157.1

Duarte, A. F. Hidrometria no Acre: clima medições e informações meteorológicas. Rio Branco: Edufac, 2007.

Duchamp, J. E.; Yates, M.; Muzika, R. M.; Swihart, R. K. Estimating probabilities of detection for bat echolocation calls: An application of the double-observer method. Wildlife Society Bulletin, p. 34, p. 408-412, 2006. https://doi.org/10.2193/00917648(2006)34[408:EPODFB]2.0.CO;2

Erickson, J. L.; West, S. D. The Influence of Regional Climate and Nightly Weather Conditions on Activity Patterns of Insectivorous Bats. Acta Chiropterologica, v. 4, no. 1, p. $17-24,2002$. https://doi.org/ $10.3161 / 001.004 .0103$

Esbérard, C. E. Efeito da coleta de morcegos por noites seguidas no mesmo local. Revista Brasileira de Zoologia, v.23, p. 1093-1096, 2006. https://doi.org/10.1590/S010181752006000400016
Faaborg, J.; Arendt, W. J.; Duggcr, K. M. Bird population studies in Puerto Rico using mist nets: General patterns and comparisons with point counts. Studies in Avian Biology, v. 29, p. 144-150, 2004

Gentry, A. H.; Emmons, L. H. Geographic variation in fertility, phenology, and composition of the understory of Neotropical forests. Biotropica, v. 19, p. 216-227, 1987. https://doi.org/10.2307/2388339

Gilardi, J. D.; Munn, C. A. Patterns of activity, flocking, and habitat parrots of the Peruvian Amazon. The Condor, v. 100, p. 641-653, 1998. https://doi.org/10.2307/1369745

Gorchov, D. L.; Cornejo, F.; Ascorra, C. F.; Ascorra, M. Dietary overlap between frugivorous birds and bats in the Peruvian Amazon. Oikos, v. 74, p. 235-250, 1995. https://doi.org/10.2307/3545653

Kalko, E. K. V. Organization and diversity of tropical bat communities through space and time. Zoology, v.101, p. 281-297, 1998.

Johnson, E. I.; Stouffer, P. C.; Vargas, C. F. Diversity, biomass, and trophic structure of a central Amazonian rainforest bird community. Revista Brasileira de Ornitologia, v. 19, p. 1-16, 2011.

Lövei, G. L.; Csörgõ, T.; Miklay, G. Capture efficiency of small birds by mist nets. Ornis Hungarica, v. 11, p. 19-25, 2001.

Marques, J. T.; Pereira, M. J. R.; Marques, T. A.; Santos, C. D.; Santana, J.; Beja, P.; Palmerim, J. M. 2013. Optimizing sampling design to deal with mist-net avoidance in amazonian birds and bats. Plos One, 8:9, e75505, 2013. https//doi.org/10.1371/journal.pone.00745 05

Mello, M. A. R.; Kalko, K. V.; Silva, W. R. Effects of moonlight on the capturability of frugivorous phyllostomid bats (Chiroptera: Phyllostomidae) at different time scales. Zoologia, v. 30, p. 397-402, 2013. https://doi.org/10.1590/S1984-46702013 000400005

Meyer, C. F. J.; Aguiar, L. M. S.; Aguirre, L. F.; Baumgarten, J.; Clarke, F. M.; Cosson, J. F.;Villegas, S. E.; Fahr, J.; Furey, D. F. N.; Henry, M.; Hodgkison, R.; Jenkins, R. K. B.; Kingston, K. G. J. T.; Kunz, T. H.; Gonzalez, M. C. M.; Patterson, I. M. B. D.; Pons, J. M.; Racey, P. A.; Rex, K.; Solari, E. M. S. S.; Stoner, K. E.; Voigt, C. C.; Staden, D.; Weise, C. D.; Kalko, E. 
K.V. Accounting for detectability improves estimates of species richness in tropical bat surveys. Journal of Applied Ecology, v. 48, p. 777-787, 2011. https://doi.org/10.1111/ j.1365-2664.2011.01976.x

O'Connor, R. J.; Hicks, R. K. The influence of weather conditions on the detection of birds during Common Birds Census fieldwork. Bird Study, v. 27, p.137-151, 1980. https://doi.org/10.1080/000636580094766 72

Oniki, Y.; Willis, E. O. Studies of ant-following birds north of the Eastern Amazon. Acta Amazonica, v. 2, no. 2, p. 127-151, 1972. https://doi.org/10.1590/1809-439219720 22127

Parmater, F. C. A Southern Hemisphere at the equator. Bulletin American Meteorological Society, v. 57, p. 1435-1440, 1976. https://doi.org/10.1175/1520-0477(1976) 057<1435:ASHCFP>2.0.CO;2

Pereira, M. J. R., Marques, J. T.; Palmeirim, J. M. Vertical stratification of bat assemblages in flooded and unflooded Amazonian forests. Current Zoology, v. 56, p. 469-478, 2010.

Presley, S. J.; Willig, M. R.; Castro-Arellano, I.; Webirdr, S. C. Effects of habitat conversion on temporal activity patterns of phyllostomid bats in lowland Amazonian rain forest. Journal of Mammalogy, v. 90, p. 210-221, 2009. https://doi.org/10.1644/08-MAMM-A089.1

R Core Team. R: A language and environment for statistical computing. Vianna: $\mathrm{R}$ Foundation for Statistical Computing, 2017.

Rex, K.; Michener, R.; Kunz, T. H; Voigt, C. C. Vertical stratification of Neotropical leafnosed bats (Phyllostomidae; Chiroptera) revealed by stable carbon isotopes. Journal of Tropical Ecology, v. 27, p. 211-222, 2011. https://doi.org/10.1017/S02664674110000 22

Reyes-Arriagada, R.; Jiménez, J. E.; Rozzi, R. Daily patterns of activity of passerine birds in a Magellanic sub-Antarctic forest at Omora Park (55 S), Cape Horn Biosphere Reserve, Chile. Polar Biology, v. 38, p. 401-411, 2015. https://doi.org/10.1007/s00300-014-15965

Rollfinke, B. F.; Yahner, R. H. Effects of time of day and season on winter bird counts. The
Condor, v. 92, p. 215-219, 1990. https://doi.org/10.2307/1368402

Rosenberg, G. H. Habitat specialization and foraging behavior by birds of Amazonian river islands in Northeastern Peru. The Condor, v. 92, p. 421-443, 1990. https://doi.org/10.2307/1368240

Rydell, J.; Speakman, J. R. Evolution of nocturnality in bats: potential competitors and predators during their early history. Biological Journal of the Linnean Society, v. 54 , p. $183-191,1995$. https://doi.org/ 10.1111/j.1095-8312.1995.tb01031.x

Salina-Melgoza, A.; Renton, K. Variation in activity patterns of Juvenile Lilac-Crowned Parrots in tropical dry forest. The Wilson Journal of Ornithology, v. 117, p. 291-295, 2005. https://doi.org/10.1676/04-096.1

Schaefer, C. E. G. R. Clima e paleoclima do Acre: memórias e cenários da aridez quaternária na Amazônia e implicações pedológicas. In: Anjos, L. H. C.; Silva, L. M.; Wadt, P. G. S.; Lumbreras, J. F.; Pereira, M. G. (Eds.). Guia de campo da IX Reunião Brasileira de Classificação e Correlação de Solos. 1. ed. Brasília: Embrapa, 2013. p. 5979.

Schnitzler, H. U.; Kalko, E. K. Echolocation by insect-eating bats. BioScience, v. 51, p. 557569, 2001. https://doi.org/10.1641/00063568(2001)051[0557:EBIEB]2.0.CO;2

Silva, J. P.; Catry, I.; Palmeirim, J. M.; Moreira, F. Freezing heat: Thermally imposed constraints on the daily activity patterns of a free-ranging grassland bird. Ecosphere, v. 6, no. 7, p.1-13, 2015. https://doi.org/ 10.1890/ES14-00454.1

Speakman, J. R.; Rydell, J.; Webb, P. I.; Hayes, J. P.; Hays, G. C.; Hulbert, I. A. R.; McDevitt, R. M. Activity patterns of insectivorous bats and birds in Northern Scandinavia $\left(69^{\circ} \mathrm{N}\right)$, during continuous midsummer daylight. Oikos, v. 88 , p. $75-86,2000$. https://doi.org/ 10.1034/j.1600-0706.2000.880109.x

Stahlschmidt, P.; Brühl, C. A. Bats as bioindicators: The need of a standardized method for acoustic bat activity surveys. Methods in Ecology and Evolution, v. 3, p. 503-508, 2012. https://doi.org/10.1111/ j.2041-210X.2012.00188.X

Stotz, D. F.; Fitzpatrick, J. W.; Parker, T. A. I.; Moskovits, D. K. Neotropical birds: Ecology 
and conservation. Chicago: The University of Chicago Press, 1996.

Terborgh, J.; Parker III, T. A.; Munn, C. A.; Pierpont, N. Structure and organization of an Amazonian forest bird community. Ecological Monograph, v. 60, p. 213-238, 1990. https://doi.org/10.2307/1943045

Thies, W.; Kalko, E. K. V.; Schnitzler, H. U. Influence of environment and resource availability on activity patterns of Carollia castanea (Phyllostomidae) in Panamá. Journal of Mammalogy, v. 87, p. 331-338, 2006. https://doi.org/10.1644/05-MAMM-A161R1.1

Trnka, A.; Szinai, P.; Hošek, V. Daytime activity of reed passerine birds based on mist-netting. Acta Zoologica Academiae Scientiarum Hungaricae, v. 52, p. 417-425, 2006.

Verde, R. S.; Silva, R. S.; Calouro, A. M. Activity patterns of frugivorous phyllostomid bats in an urban fragment in southwest Amazonia,
Brazil. Iheringia, Série Zoologia, v. 108, p. e2018016, 2018. https://doi.org/10.1590/ $1678-4766 \mathrm{e} 2018016$

Voigt, C. C.; Kingston, T. Bats in the Anthropocene. In: Vogt, C. C.; Kington, T. (Ed.). Bats in the Anthropocene: Conservation of bats in a changing world. New York: Springer, 2016. p. 1-9.

Whitman, A. A. Use of mist nets for study of Neotropical bird communities. Studies in Avian Biology, v. 29, p. 161-167, 2004.

Willis, E. O.; Oniki, Y. Birds and army ants. Annual Review of Ecology and Systematics, v. 9, no. 1, p. 243-263, 1978. https://doi.org/10.1146/annurev.es.09.1101 78.001331

Wilman, H.; Belmaker, B.; Simpson, J.; De La Rosa, C.; Rivadeneira, M. M.; Jetz, W. EltonTraits 1.0: Species-level foraging attributes of the world's birds and mammals. Ecology, v. 95, no. 7, p. 207-207, 2014. https://doi.org/10.1890/13-1917.1 